\title{
Strategic Marketing Analysis of Premium Package Products of Joint Stock Investment Commercial Bank "Tatfondbank"
}

\author{
Novenkova A. Z. ${ }^{1}$, Shakirzyanov R. Sh. ${ }^{1} \&$ Gilmanova A. A. ${ }^{2}$ \\ ${ }^{1}$ Institute of Management, Economics and Finance, Kazan Federal University, Kazan, Russia \\ ${ }^{2}$ Institute of Language, Kazan Federal University, Kazan, Russia \\ Correspondence: Novenkova A. Z., Institute of Management, Economics and Finance, Kazan Federal University, \\ Kazan, 420008, Russia.
}

Received: March 10, 2015 Accepted: March 31, 2015 Online Published: April 30, 2015

doi:10.5539/ass.v11n11p188

URL: http://dx.doi.org/10.5539/ass.v11n11p188

\begin{abstract}
The work of banking institutions is diverse. Their activity is an integral and significant part of market economy of a country. The result of the work of a lending institution is a banking product as the product of corporate efforts of a bank personnel as a whole, but not of an individual bank employee.

A banking product, as any other product yielded in market environment, should primarily meet the needs of its clients. Its development and implementation is accomplished in accordance with adopted strategy of development of a certain bank, aimed at the increase of client base, rendering qualitative service, profit making, cost saving etc.

As part of working on performance evaluation and marketing strategy construction, we would like to dwell on the issue of a current trend in the modern multifaceted banking sector of Private banking (or VIP servicing facility) using the example of one of the major players in the market of Russian banking services - Joint Stock Investment Commercial Bank "Tatfondbank".
\end{abstract}

Keywords: marketing strategy, private banking, product, vip banking service

\section{Introduction}

Joint stock investment commercial bank "Tatfondbank" is a universal bank with state participation, which renders all kinds of banking services to individual and corporate customers. The Bank was established in 1994.

Tatfondbank is among 50 largest banks of Russia in assets. For September 1, 2014 its assets totalled RUB 154 billion and its equity - RUB 18.9 billion. The Bank's charter capital was RUB 12.6 billion.

\subsection{Review of the Banking Sector in the Russian Federation on the Results of 2014}

As the result of the banking institutions' activity in the Russian Federation for 8 months of 2014, according to the Central bank of Russia's data, the following trend in the growth of assets and liabilities can be observed:

- Loans to legal entities: the growth rate in the RF is $111,8 \%$, Tatfondbank is $116,5 \%$.

- Loans to retail customers: the growth rate in the RF is $110,1 \%$, Tatfondbank is $99,6 \%$.

- The assets of legal entities on corporate accounts: the growth rate in the RF is $99,9 \%$, Tatfondbank is $102,7 \%$.

- The assets of retail customers on accounts: the growth rate in the RF is $101,8 \%$, Tatfondbank is $105,4 \%$.

It should be mentioned, that the Tatfondbank's rates are generally slightly higher than comparable growth rates in the banking sector in the Russian Federation (Larionova \& Varlamova, 2013). The only exception is the slight retardation in the growth rate of loans provided to retail customers, which was determined by the temporary cease in granting unsecured loans (credit cards) in the 2nd quarter of the current year (See Figures 1-2). Similar process could be observed in many Russian retail banks.

This comparison lets us conclude the rightness of the bank's business strategy in the conditions of a difficult economic situation, when further deceleration in the banking sector is expected in 2015, as well as the diversification of its risks. 


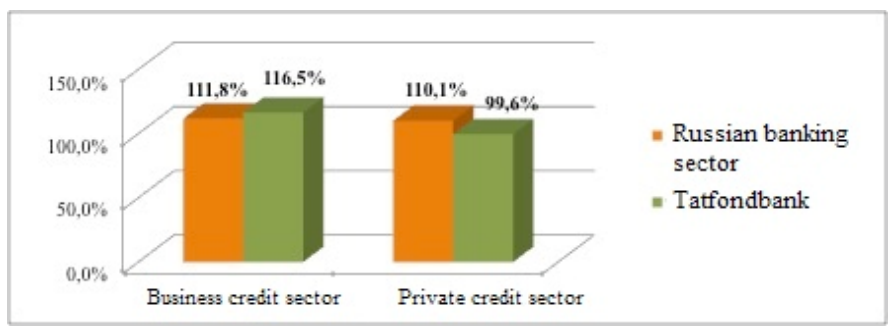

Figure 1. Growth rate of assets structure

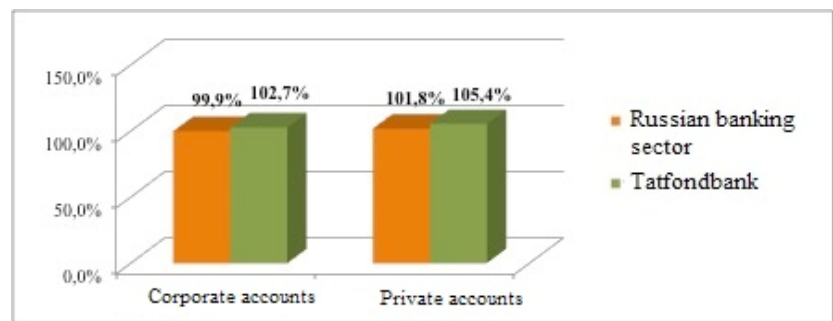

Figure 2. Growth rate of liability structure

In these conditions, it is necessary to search for alternative sources of income, less liable to variations in economy, of which the perspective direction of Private Banking seems to be the example (Safiullin, Ismagilova, Gallyamova, \& Safiullin, 2013).

\section{Private Banking}

Private banking is a set of banking services, rendered to an affluent private person, usually accompanied by a personal manager of a credit institution. Private banking is also commonly referred to as VIP service.

In its classical presentation, Private Banking offers its clients 3 types of products: banking (which includes deposits, loans, credit cards, bank-managed mutual funds), investment and advisory service (Safiullin, Ismagilova, Safiullin, \& Bagautdinova, 2012). In fact, these are the same banking services available for regular clients, but offering facilities that are more individual. For example, credits on favourable terms, deposits on favourable conditions etc. In most cases, a VIP client may expect to communicate with the head of the unit/subsidiary of a bank in a detached office (usually with luxurious setting) away from prying eyes. The level of "individual approach" in financial service is determined by the size of assets brought to the bank: the more the client brings, the more preferential the treatment is.

In the Russian banking sphere there is no single standard of Private Banking, as a result, every lending institution settles its own parameters of an "entry ticket" and doesn't reveal it conditions to public. Therefore, the competitors may only guess about the conditions of a bank, or obtain information by means of industrial intelligence (Safiullin, Elstin, \& Shakirova, 2012). In their own turn, the clients learn about the bank's offers at private meetings with their personal managers.

Products in private banking segments are piece goods and are not sold in bulk. Here it is important to evaluate a client before offering a certain product (for instance, to analyze the existing client's behaviour based on the data of the used products - deposits, salary cards etc.). The further quality of a premium client base portfolio, the proper use of products and achievement of further results by the bank will depend on it.

The study of the client's behaviour also helps the bank to run specials, to conclude temporary partnership agreements with retail trading organizations, which are aimed at stimulating cardholders to use their payment instrument more often and increase non-cash transactions on cards (Kirshin, 2014a).

\subsection{Private Banking in Tatfondbank}

Some years ago, Tatfondbank developed mainly as a corporate customer bank. Now it is actively developing as a retail business, performing credit financing, deposit taking, rendering the set of premium banking facilities for private customers. The last direction is one of the key business lines.

Tatfondbank came into the market of affluent customer service in 2011, having offered a broad range of services, which includes advantages of private banking, special privileges and extended complex of instruments for financial and nonfinancial solutions. 
From the beginning of the Bank's development in Mass Affluent segment, its customer base has been steadily increasing due to the most individual, personalized and status service, high quality product offer and expansion of the Bank to the regions (Kirshin, 2014b).

In 2013, the Bank introduced a new offer for wealthy customers, having designed a package of services with the premium card of the highest category MasterCard Black Edition. With account for requirements of the Russian market and basing on the global practice, in 2013, the Bank increased barriers to enter Mass Affluent service up to RUB1 million.

In May 2014, Tatfondbank extended the range of premium products with the premium quality Visa Infinite card.

Currently Tatfondbank offers the following saturation of premium (packaged) products (in the order of increasing price of service accordingly):

- Platinum

- Elite

- Deluxe

The main difference between packaged products of a bank is the type of a card product, service charge, saturation with additional services. For instance, in the premium quality packages, additional Priority Pass cards are offered for the clients and members of their families (friends, colleagues), who are allowed to be housed in VIP lounges of airports around the world and get an increased cash-back to the card.

Decomposition of a packaged product:

- Card products: Visa/MasterCard Platinum cards, MasterCard Black Edition, Visa Infinite (including additional free cards for members of families).

- Deposits

- Loans

- Remote banking (including SMS-banking service)

- Bank-managed Mutual Funds/Mutual Investment Funds

- Personal service: availability of a personal manager, concierge services, VIP service area.

- Loyalty programs: cash-back to the card, Priority Pass cards, special discounts when buying precious coins or ingots.

To promote premium products, the Bank chose its slogan as "Personal privileges for the chosen", aimed at showing individual approach with offering banking and nonbanking services for those clients who tend to emphasize their status, power and personal success (Ankudinov \& Lebedev, 2014a).

\subsection{Using Cards by Clients as the Main Instrument of Premium Product}

Table 1. SWOT analysis of private banking segment

\begin{tabular}{|c|c|c|}
\hline & Positive influence & Negative influence \\
\hline 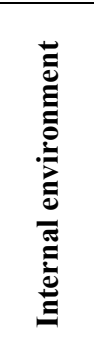 & $\begin{array}{l}\text { Strengths: } \\
\text { - Brand recognition in the region } \\
\text { - The bank with state image } \\
\text { - The Prime Minister of the Republic of } \\
\text { Tatarstan is in the bank's Board of Directors } \\
\text { - Wide-area network of offices } \\
\text { - Weak representation of the segment by other } \\
\text { regional players } \\
\text { - The Institute of personal managers }\end{array}$ & $\begin{array}{l}\text { Weaknesses: } \\
\text { - } \quad \text { Possible faults of personal managers }\end{array}$ \\
\hline 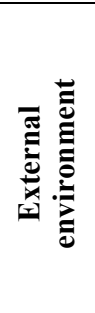 & $\begin{array}{l}\text { Opportunities: } \\
\text { - Weak impact of negative changes in economy } \\
\text { on the segment (the clients are less exposed to } \\
\text { default) } \\
\text { - The bank with state image } \\
\text { - Wide-area network of offices } \\
\text { - The Institute of personal managers } \\
\text { - Positive feedback from existing clients }\end{array}$ & $\begin{array}{l}\text { Threats: } \\
\text { - Large amount of federal players } \\
\text { - Aggressive policy of federal market players } \\
\text { - Weak brand recognition outside the Republic of } \\
\text { Tatarstan } \\
\text { - Possible faults of personal managers }\end{array}$ \\
\hline
\end{tabular}


Plastic cards of international payment systems are one of the essential components of saturation of premium package for affluent clients (Ankudinov, \& Lebedev, 2014b). This instrument provides its holder with various bonuses (as a compensation, interest on arrears, credit card grace period etc.) as well as spiritual gratification with the status of the card. Premium Visa Platinum, MasterCard Black Edition and Visa Infinite cards are aimed to emphasize the status of their holders.

A card is usually an instrument for remote access to the client's accounts, which is usually positioned as a tool for non-cash payments for goods and services. In this context, the result is obvious, as the segment of affluent clients who obtain the bank's premium packaged products is its qualitative part. Affluent clients use cards mainly for the purposes of non-cash payments.

The Bank also receives certain fee income based on this element, for example, interest charges, cost of premium package service, benefits from payment systems for non-cash card transactions when paying for goods and services. The last is a stimulus for a bank to increase the volume of such transactions, which is encouraged by international payment systems of Visa and MasterCard, and to follow the requirements of the bank regulator the Central Bank of the Russian Federation.

\section{Conclusion}

One of the main factors of favourable development of Private Banking segment is the fact that it is slightly exposed to the influence of negative changes in the economy of the country, the clients of this segment are less exposed to default. Therefore, one of the main objectives of the bank will be pursuit of capitalization of the brand, emphasizing its image component.

Thus, as the result of August 2014, Tatfondbank entered the top-20 of most mass media-quoted Russian banks and top- 15 of the most expensive banking brands in the Russian Federation.

Indeed, the fact that the Prime Minister of the Republic of Tatarstan Ildar Khalikov was elected the Chairman of the Board of Directors played an important role.

Participation in different ratings, mass citation of the bank will allow to lower risks associated with brand recognition outside the Republic of Tatarstan and, as a result, will create favourable atmosphere for operation and developing its products in the premium segment.

Within the framework of development, the following promotion channels for premium products are investigated:

- the offices of the Bank

- Participation in city events for affluent clients (forums, exhibitions, conferences).

- Placing information about the product in glossy magazines, distributed in restaurants/VIP airport zones etc.

- Holding presentations at invitation parties (in golf clubs etc.)

- Feedback from existing clients.

The main aims of the Bank in promoting Private Banking are:

- Consolidating the positions of the Bank in the segment

- Expanding services in the segment, taking into account the increased demands of clients in the segment

- Expansion of Private Banking to regional units

- Building the ideology of Wealth Management and Family Office.

The targets for increasing customer base are:

- The existing client base (based on CRM research of clients' behaviour)

- Top-managers of companies and state institutions

- Celebrities (sportsmen, actors etc.)

- Business-, expensive real estate-, cars owners

- Relatives of existing clients

Common performance targets of the Bank in developing the direction in 2015 are:

- Increase in the amount of sold products from 4 to 7 per one personal manager a month

- Reaching the $2 \%$ volume of premium products in the current emission of bank cards 
To achieve these results, the bank introduces the following KPI indicators in the appraisal system of staff performance:

- Selling packages for total amount of fee income RUB x1

- Prolongation of packages (no less than $80 \%$ of existing packages)

- Attraction of bank deposits - no less than RUB x2

- Selling coins to the amount of no less than RUB x3

- Selling bank-managed mutual funds for no less than RUB x4

- Attracting no less than 5 organizations to cash and settlement service.

\section{References}

Ankudinov, B., \& Lebedev, O. V. (2014a). Investment drivers of shareholder value creation in large publicly traded Russian companies. Investment Management and Financial Innovations, 11(2), 77-85.

Ankudinov, B., \& Lebedev, O. V. (2014b). Job insecurity and employees' motivation to engage in professional education. American Journal of Applied Sciences, 11(5), 860-865. http://dx.doi.org/10.3844/ajassp. 2014.860.865

Bagautdinova, N. G., Gafurov, I. R., \& Novenkova, A. Z. (2013). The transformation of region's economic area governed by the development of industrial region. World Applied Sciences Journal, 25(7), 1113-1117.

Hanssens, H., Derudder, B., \& Witlox, F. (2013). Are advanced producer services connectors for regional economies? An exploration of the geographies of advanced producer service procurement in Belgium. Geoforum, 12-21. http://dx.doi.org/10.1016/j.geoforum.2013.02.004

Kirshin, I. A. (2014a). Ecological Restrictions of Modern Economic Growth ISSN 1075_7007. Studies on Russian Economic Development, 25(3), 276-282. http://dx.doi.org/10.1134/S1075700714030046

Kirshin, I. A. (2014b). Modeling the long-term trend of accumulation of knowledge. Life Science Journal, 11(6s), 482-486.

Larionova, N. I., \& Varlamova, Yu. A. (2013). The Trends of Household Economic Behavior in International Comparison. Procedia Economic and finance, 5, 737-746. http://dx.doi.org/10.1016/S2212-5671 (13)00086-5

Panasyuk, M. V., Novenkova, A. Z., Chalova, A. I., \& Yu Anopchenko, T. (2013). Region in the international economic cooperation system. World Applied Sciences Journal, 27(13), 145-148.

Safiullin, L. N., Ismagilova, G. N., Gallyamova, D. Kh., \& Safiullin, N. Z. (2013). Consumer benefit in the competitive market. Procedia Economic and finance, 5, 667-676. http://dx.doi.org/10.1016/S2212-5671 (13)00078-6

Safiullin, L. N., Ismagilova, G. N., Safiullin, N. Z., \& Bagautdinova, N. G. (2012). The development of welfare theory in conditions of changes in the quality of goods and services. World Applied Sciences Journal, 18, 144-149.

Safiullin, M. R., Elstin, L. A., \& Shakirova, A. I. (2012). Evaluation of business and economic activity as a short-term forecasting tool. Herald of the Russian Academy of Sciences, (4), 290-294. http://dx.doi.org/10.1134/S1019331612040053

\section{Copyrights}

Copyright for this article is retained by the author(s), with first publication rights granted to the journal.

This is an open-access article distributed under the terms and conditions of the Creative Commons Attribution license (http://creativecommons.org/licenses/by/3.0/). 